\title{
Perbedaan Nilai The Clinic GBS Severity Evaluation Scale (CGSES) dan Skala Disabilitas Sindroma Guillain-Barre (SDSGB) pada Pasien Sindroma Guillian Barre dengan dan tanpa Imunoterapi
}

\author{
Berliana Sidabutar ${ }^{*}$, Ahmad Rizal Ganiem**), Nushrotul Lailiyya ${ }^{* *}$, Nani Kurniani ${ }^{* *}$, Lisda Amalia**), \\ Sobaryati**) $^{* *}$ \\ Departemen Neurologi, Fakultas Kedokteran, Universitas Padjajaran, RSUP dr. Hasan Sadikin Bandung
}

\begin{abstract}
Abstrak
Latar Belakang dan Tujuan: The Clinical GBS Severity Evaluation Scale (CGSES) dikembangkan untuk penentuan imunoterapi pasien Sindroma Guillian Barre (SGB) secara lebih obyektif. Skala Disabilitas SGB (SDSGB) menggambarkan tingkat keparahan SGB dan dapat digunakan menilai efektifitas pemberian imunoterapi. Tujuan penelitian untuk mengetahui perbedaan penilaian CGSES dan SDSGB pasien SGB dengan dan tanpa imunoterapi dan membandingkan kesesuaian keputusan subyektif dengan CGSES.

Subjek dan Metode: Penelitian observasional analitik potong lintang komparatif secara retrospektif pada pasien rawat SGB periode Januari 2015 - Maret 2020 di RSUP Dr Hasan Sadikin Bandung.

Hasil: Terdapat 92 subjek (35 dengan dan 57 tanpa imunoterapi). Rerata usia 41,5 tahun, dengan pria:wanita (57,6\%:42,4\%). Tidak didapatkan perbedaan demografi dan pemeriksaan fisik kedua kelompok, kecuali paresis saraf kranial (62,9\% vs. 33,3\%; $p=0,006)$. Terdapat perbedaan rerata lama perawatan dengan dan tanpa imunoterapi $(29,5 \pm 34,4$ vs. $11,4 \pm 4,1$ hari, $\mathrm{p}=0,0001)$. Hasil penilaian CGSES pasien SGB dengan dan tanpa imunoterapi memiliki perbedaan bermakna $(\mathrm{p}=0,035)$. Terdapat perbedaan signifikan SDSGB saat masuk dan pulang pasien dengan imunoterapi $(p=0,007)$ dan tanpa imunoterapi $(p=0,025)$. Terdapat ketidaksesuaian keputusan subyektif dengan nilai CGSES (nilai Kappa 0,117; CI95\% 0,021-0,213)

Simpulan: Terdapat perbedaan skor CGSES dan SDSGB pada kelompok pasien SGB dengan dan tanpa imunoterapi. Terdapat ketidaksesuaian penilaian subyektif keputusan pemberian imunoterapi dengan skoring CGSES
\end{abstract}

Kata kunci: CGSES, imunoterapi, SDSGB, Sindroma Guillain-Barre

JNI 2021; 10 (2): 80-90

\section{Differences in Value of The Clinic GBS Severity Evaluation Scale (CGSES) and Guillain- Barre Syndrome Disability Scale (GBSDS) in Guillian Barre Syndrome (GBS) Patients with and without Immunotherapy}

\begin{abstract}
Background and objective: The Clinical GBS Severity Evaluation Scale (CGSES) was developed to determine immunotherapy of GBS patients more objectively. GBS Disability Scale (SDSGB) describes severity of GBS and assesses effectiveness of immunotherapy. Purpose of this study was to measure difference of CGSES and GBSDS in GBS patients with and without immunotherapy and to compare the suitability of subjective decisions with CGSES. Subject and Methods: This is a comparative cross-sectional analytic observational study retrospectively in GBS patients from January 2015-March 2020 hospitalized at Dr Hasan Sadikin Hospital, Bandung.

Results: There were 92 subjects (35 with and 57 without immunotherapy). Mean age was 41.5 years, and male:female ratio was $57.6 \%: 42.4 \%$. There were no differences in demographics and physical examination between two groups, except for cranial nerve paresis $(62.9 \%$ vs. $33.3 \%$; $\mathrm{p}=0.006)$. There was a difference in mean length of stay with and without immunotherapy $(29.5 \pm 34.4$ vs. $11.4 \pm 4.1$ days, $\mathrm{p}=0.0001)$. Results of the CGSES assessment with and without immunotherapy had a significant difference $(\mathrm{p}=0.035)$. There were significant differences in GBSDS at admission and discharge with $(\mathrm{p}=0.007)$ and without immunotherapy $(\mathrm{p}=0.025)$. There was a discrepancy between subjective decisions and CGSES value (Kappa value 0.117 ; $95 \%$ CI 0.021-0.213).

Conclusion: There were differences in CGSES and GBSDS in group of GBS patients with and without immunotherapy. There was a discrepancy between subjective assessment of decision to give immunotherapy with CGSES scoring.
\end{abstract}

Key words: CGSES,GBS Disability Scale, Guillain Barre Syndrome, Immunotherapy

JNI 2021; 10 (2): 80-90

This article is licensed under

Creative Commons Attribution-NonCommercial-ShareAlike 4.0 International License.

OBerliana Sidabutar, Ahmad Rizal Ganiem, Nushrotul Lailiyya, Nani Kurniani, Lisda

Amalia, Sobaryati

(2021) under the CC-BY-NC-SA license 


\section{Pendahuluan}

Sindroma Guillain-Barré (SGB) merupakan suatu sindroma yang disebabkan oleh proses autoimun terhadap saraf perifer akut dengan progresifitas cepat, dengan gejala dan tanda berupa kelemahan keempat anggota gerak, reflex tendon yang hilang dan terganggunya sensibilitas seperti kesemutan atau kebas. ${ }^{1}$ Insidensi SGB 0,811,89 kasus per 100.000 penduduk, meningkat seiring bertambahnya usia, serta lebih sering terjadi pada laki-laki dibandingkan perempuan dengan perbandingan 3:2.1,2 Angka mortalitas SGB adalah sebesar 9\% dan tingkat disabilitas mencapai $17 \% .^{3}$ Imunoterapi secara signifikan meningkatkan jumlah pasien yang pulih kekuatan ototnya penuh dan menurunkan proporsi pasien dengan gejala sisa motorik yang berat setelah satu tahun, sehingga secara umum memperbaiki luaran dibandingkan dengan perawatan suportif saja. ${ }^{4}$ Keputusan menjalani imunoterapi seringkali didasarkan pada pertimbangan subyektif dokter yang memberikan pelayanan. Suatu sistem penilaian yang baru yaitu CGSES (The Clinic GBS Severity Evaluation Scale) dikembangkan dan divalidasi di Cina pada tahun 2017 dan dapat digunakan sebagai alat prediksi luaran secara dini terhadap tingkat keparahan SGB dan dipakai untuk membantu pertimbangan pemberian imunoterapi berdasarkan temuan obyektif saat onset awal. ${ }^{5}$ Penilaian berdasarkan 4 (empat) parameter klinis yaitu durasi hari antara awitan sampai masuk RS, keluhan utama berupa kelemahan, abnormalitas sensorik dan keterlibatan saraf kranial. Dengan menggunakan sistem CGSES ini para klinisi dapat memperkirakan keparahan, luaran dan pemberian terapi hanya dengan mengetahui keluhan utama pasien SGB. ${ }^{5}$ Selain itu Skala Disabilitas SGB (SDSGB) merupakan suatu skoring yang menggambarkan tingkat keparahan SGB. SDSGB mempunyai rentang nilai 0 (normal) hingga 6 (kematian) dan pada SDSGB kemampuan berjalan dijadikan patokan prognosis di mana SDSGB $\geq 3$ didefinisikan sebagai luaran buruk. ${ }^{2}$ Pemberian imunoterapi dapat mempercepat pemulihan dari pasien SGB ditandai dengan peningkatan satu poin atau lebih pada SDSGB setelah 4 minggu, dibandingkan tanpa pemberian imunoterapi. ${ }^{6}$
Penilaian CGSES untuk membantu keputusan imunoterapi ini belum pernah dilakukan di Indonesia sehingga dipandang perlu membandingkan keputusan subyektif pemberian imunoterapi dengan skala yang baru ini. Selain itu ingin dilakukan perbandingan perbedaan luaran saat keluar dari rumah sakit antara kelompok yang menjalani imunoterapi dengan yang tidak dengan menggunakan SDSGB.

\section{Metode}

Penelitian ini merupakan penelitian observasional analitik dengan rancangan penelitian potong lintang (cross sectional) komparatif. Data diambil secara retrospektifdarirekammedis pasiendengan diagnosis SGB yang menjalani perawatan inap di RSUP Dr Hasan Sadikin (RSHS) Bandung sejak Januari 2015 sampai dengan Maret 2020. Kriteria inklusi yaitu dewasa ( $\geq 18$ tahun) dan pasien yang telah terdiagnosis klinis SGB dalam rekam medis dan sudah disetujui oleh dokter Spesialis Saraf sebagai dokter penanggung jawab. Pasien dengan data rekam medik yang tidak lengkap dan jumlah imunoterapi kurang dari tiga kali dikeluarkan dari penelitian. Studi ini disetujui oleh Komisi Etik Penelitian Universitas Padjajaran dengan nomor persetujuan 389/UN6.KEP/EC/2020. Penentuan besar sampel dilakukan berdasarkan perhitungan statistik dengan menggunakan rumus

$n_{1}=n_{2}=2\left(\frac{\left(Z_{\alpha}+Z_{\beta}\right) S}{X_{1}-X_{2}}\right)^{2} \begin{aligned} & \text { Total jumlah } \\ & \text { sampel seluruhnya } \\ & \text { adalah 92 orang }\end{aligned}$

Analisis statistik menggunakan program SPSS versi 24.0 for Windows. Untuk mengetahui bagaimana perbedaan hasil penilaian CGSES pasien SGB dengan dan tanpa imunoterapi menggunakan uji chi-square dengan nilai kemaknaan $\mathrm{p}<0,05$. Perbedaan SDSGB saat masuk dan pulang dari rumah sakit pada pasien dengan dan tanpa imunoterapi dihitung dengan menggunakan uji Wilcoxon dengan nilai $\mathrm{p}<0,05$ dianggap bermakna. Kesesuaian keputusan klinis dokter penanggung jawab dengan nilai CGSES dinilai dengan menggunakan perhitungan nilai 
Kappa $(\kappa)$, dengan nilai $\kappa$ yang ideal adalah 1 , namun nilai $>0,8$ dianggap sudah sangat baik.

\section{Hasil}

Selama periode penelitian didapatkan 110 subjek yang terkumpul. Delapan subjek dieksklusi karena data yang tidak lengkap, 5 subjek karena terbukti bukan SGB dan 5 subjek dengan jumlah Plasma Exchange (PE) kurang dari 3 kali, sehingga didapatkan 92 pasien SGB yang memenuhi syarat penelitian, terdiri dari 35 subjek yang menjalani imunoterapi dan 57 subjek tanpa imunoterapi. Dua subjek mendapatkan imunoterapi berupa intravenous immunoglobulin (IVIG) dan 33

Tabel 1. Deskripsi Skala Disabilitas Berdasarkan Kekuatan Motorik

\begin{tabular}{|c|c|c|}
\hline $\begin{array}{l}\text { Skala } \\
\text { Disabilitas }\end{array}$ & Deskripsi & Kekuatan Motorik \\
\hline 0 & Sehat & 5 \\
\hline 1 & $\begin{array}{l}\text { Gejala ringan dan } \\
\text { masih bisa berlari }\end{array}$ & $\begin{array}{l}5 \quad \text { (ada gejala } \\
\text { ringan } \\
\text { baal) }\end{array}$ \\
\hline 2 & $\begin{array}{l}\text { Bisa berjalan } \\
\text { sejauh } 10 \text { meter } \\
\text { tanpa bantuan, } \\
\text { tetapi tidak bisa } \\
\text { berlari }\end{array}$ & $\begin{array}{l}4 \text { (baik proximal } \\
\text { dan distal) }\end{array}$ \\
\hline 3 & $\begin{array}{l}\text { Berjalan sejauh } \\
10 \text { meter dengan } \\
\text { bantuan }\end{array}$ & $\begin{array}{l}3 \text { (baik proksimal } \\
\text { dan distal) }\end{array}$ \\
\hline 4 & $\begin{array}{l}\text { Tirah baring atau } \\
\text { bergantung pada } \\
\text { kursi roda }\end{array}$ & $\begin{array}{l}2,1, \text { dan } 0 \text { (bila } \\
\text { duduk proximal } \\
\text { harus 3, distal bisa } \\
2 \text { atau 1) }\end{array}$ \\
\hline 5 & $\begin{array}{l}\text { M e m e r l u ka n } \\
\text { b a n u a n } \\
\text { ventilasi dalam } \\
\text { kesehariannya }\end{array}$ & Sesuai \\
\hline 6 & Meninggal & Sesuai \\
\hline
\end{tabular}

Keterangan : Untuk Skala disabilitas $\leq 3$ (Bisa verjalan) kekuatan motrorik ekstremitas superior haruslah minimal 3

mendapatkan PE. Data demografik dan temuan klinis saat pasien masuk rumah sakit dapat dilihat pada Tabel 2. Tidak didapatkan perbedaan rerata usia pada kedua kelompok $(40,3 \pm 14,2$ vs. $42,5 \pm 14,4 ; \mathrm{p}=0,460)$. Pada kedua kelompok, subjek laki-laki sedikit lebih banyak dari pada wanita. $(57,1 \%$ vs. $42,9 \%$ pada kelompok pasien dengan imunoterapi, dan $57,9 \%$ vs. $42,1 \%$ pada kelompok tanpa imunoterapi). Tidak didapatkan perbedaan temuan klinis yang bermakna pada kedua kelompok, kecuali kejadian paresis saraf kranial ditemukan lebih banyak pada kelompok dengan imunoterapi $(62,9 \%$ vs. $33,3 \%$; $p=0,006)$. Kejadian anteseden didapatkan lebih banyak pada kelompok dengan imunoterapi, namun perbedaannya tidak signifikan ( $74,3 \%$ vs. $56,1 \%$, $\mathrm{p}=0,08)$. Kejadian anteseden yang tersering adalah diare dan infeksi saluran nafas (masing-masing $34,3 \%$ ) pada kelompok dengan imunoterapi sedangkan pada kelompok tanpa imunoterapi, infeksi saluran nafas sebesar $26,3 \%$ dan infeksi diare sebesar $17,54 \%$. Terdapat sebanyak 2 subjek $(5,7 \%)$ pada kelompok imunoterapi dan 7 subjek $(12,3 \%)$ pada kelompok tanpa imunoterapi dengan kejadian anteseden selain diare dan infeksi saluran nafas (seperti kondisi hamil).

Varian SGB terbanyak pada kedua kelompok adalah AMSAN $(51,4 \%$ pada kelompok dengan imunoterapi dan 57,9\% pada kelompok tanpa imunoterapi). Terdapat 6 subjek yang tidak diketahui variannya karena meninggal sebelum pemeriksaan KHS. Tidak didapatkan perbedaan signifikan pada varian SGB antara kedua kelompok. Terdapat perbedaan rata-rata durasi awitan sampai pasien dibawa ke rumah sakit pada kedua kelompok (kelompok dengan imunoterapi 4,5 $\pm 2,6$ hari, sedangkan pada kelompok tanpa imunoterapi 5,8 $\pm 4,7$ hari), namun tidak berbeda secara statistik $(\mathrm{p}=0,379)$. Durasi awitan sampai imunoterapi adalah selama $8,2 \pm 4,3$ hari. Rata-rata lama rawat pada kelompok dengan imunoterapi secara signifikan lebih panjang daripada yang tidak menjalani imunoterapi (29,5 $\pm 34,4$ hari vs. $11,4 \pm 4,1$ hari; $\mathrm{p}=0,0001)$. Terdapat $5(14,3 \%)$ subjek yang meninggal pada kelompok dengan imunoterapi dan 1 subjek $(1,8 \%)$ yang meninggal pada kelompok tanpa imunoterapi $(p=0,028)$. Rata-rata durasi awitan sampai meninggal pada subjek dengan imunoterapi adalah selama 23,8 hari, sedangkan pada subjek tanpa imunoterapi 18 hari. Secara statistik perbedaan proporsi ini tidak bermakna $(\mathrm{p}=0,777)$. Tidak didapatkan perbedaan median 
Perbedaan Nilai The Clinic GBS Severity Evaluation Scale (CGSES) dan Skala Disabilitas Sindroma Guillain-Barre

(SDSGB) pada Pasien Sindroma Guillian Barre dengan dan tanpa

Imunoterapi

Tabel 2.1 Perbandingan antara Karakteristik Subjek Penelitian dengan dan Tanpa Imunoterapi

\begin{tabular}{|c|c|c|c|}
\hline \multirow[t]{2}{*}{ Variabel } & \multicolumn{2}{|l|}{ Kelompok } & \multirow[t]{2}{*}{ Nilai $\mathrm{P}$} \\
\hline & Dengan Imunoterapi $n=35$ & Tanpa Imunoterapi $n=57$ & \\
\hline Usia (tahun) & & & 0,460 \\
\hline Mean \pm Std & $40,3 \pm 14,2$ & $42,5 \pm 14,4$ & \\
\hline Median & 39,00 & 43,00 & \\
\hline Range (min-max) & $17,00-72,00$ & $18.00-78,00$ & \\
\hline Kategori Usia & & & 0,845 \\
\hline$>60$ tahun & $5(14,3 \%)$ & $9(15,8 \%)$ & \\
\hline$\leq 60$ tahun & $30(85,7 \%)$ & $48(84,2 \%)$ & \\
\hline Jenis Kelamin & & & 0,944 \\
\hline Laki-laki & $20(57,1 \%)$ & $33(57,9 \%)$ & \\
\hline Perempuan & $15(42,9 \%)$ & $24(42,1 \%)$ & \\
\hline Kejadian Anteseden & & & 0,080 \\
\hline Ada & $26(74,3 \%)$ & $32(56,1 \%)$ & \\
\hline Tidak ada & $9(25,7 \%)$ & $25(43,9 \%)$ & \\
\hline Defisit Sensorik & & & 0,315 \\
\hline Ada & $23(65,7 \%)$ & $43(75,4 \%)$ & \\
\hline Tidak ada & $12(34,3 \%)$ & $14(24,6 \%)$ & \\
\hline Defisit Motorik & & & 0,285 \\
\hline Ada & $35(100 \%)$ & $54(94,7 \%)$ & \\
\hline Tidak ada & $0(0 \%)$ & $3(5,3 \%)$ & \\
\hline Paresis saraf kranial & & & $0,006^{*}$ \\
\hline Ada & $22(62,9 \%)$ & $19(33,3 \%)$ & \\
\hline Tidak Ada & $13(37,1 \%)$ & $38(66,7 \%)$ & \\
\hline Varian SGB & & & 0,999 \\
\hline AIDP $\dagger \dagger$ & $3(9,7 \%)$ & $2(3,6 \%)$ & \\
\hline AMAN $\S \S$ & $10(32,2 \%)$ & $20(36,4 \%)$ & \\
\hline AMSAN \#\# & $18(58,1 \%)$ & $33(60 \%)$ & \\
\hline Durasi awitan - RS (hari) $\dagger$ & & & 0,379 \\
\hline Mean \pm Std & $4,5 \pm 2,6$ & $5,8 \pm 4,7$ & \\
\hline Median & 4,00 & 5,00 & \\
\hline Range (min-max) & $1,00-14,00$ & $1,00-21,00$ & \\
\hline \multicolumn{4}{|c|}{ Durasi awitan - Imunoterapi (hari)§ } \\
\hline Mean \pm Std & $8,2 \pm 4,3$ & - & \\
\hline Median & 7,00 & - & \\
\hline Range (min-max) & $2,00-21,00$ & - & \\
\hline
\end{tabular}

Keterangan : *Nilai $\mathrm{p}<0,05$. $\dagger$ Durasi awitan $-\mathrm{RS}$ adalah rentang waktu antara mulai awitan SGB hingga masuk RS. $\S$ Durasi awitan - imunoterapi adalah rentang waktu antara mulai awitan SGB hingga dilakukan imunoterapi. \#Durasi awitan - meninggal adalah rentang waktu antara mulai awitan SGB hingga pasien meninggal †† AIDP (Acute Inflammatory Demyelinating Polyradiculoneuropathy). §§ AMAN (Acute Motor Axonal Neuropathy). \#\# AMSAN (Acute Motor Sensory Axonal Neuropathy). KHS dikerjakan pada 31 subjek dengan imunoterapi dan 55 subjek tanpa imunoterapi. 
Tabel 2.2 Perbandingan antara Karakteristik Subjek Penelitian dengan dan Tanpa Imunoterapi

\begin{tabular}{|c|c|c|c|}
\hline \multirow[t]{2}{*}{ Variabel } & \multicolumn{2}{|l|}{ Kelompok } & \multirow[t]{2}{*}{ Nilai $P$} \\
\hline & Dengan Imunoterapi $n=35$ & Tanpa Imunoterapi $n=57$ & \\
\hline Lama rawat & & & $0,0001 *$ \\
\hline Mean \pm Std & $29,5 \pm 34,4$ & $11,4 \pm 4,1$ & \\
\hline Median & 21,00 & 11,00 & \\
\hline Range (min-max) & $6,00-204,00$ & $4,00-26,00$ & \\
\hline Outcome & & & $0,028^{*}$ \\
\hline Hidup & $30(85,7 \%)$ & $56(98,2 \%)$ & \\
\hline Meninggal & $5(14,3 \%)$ & $1(1,8 \%)$ & \\
\hline Durasi awitan - meninggal $(\mathrm{N}=6)$ \# & & & 0,777 \\
\hline Mean \pm Std & & & \\
\hline Median & & & \\
\hline Range (min-max) & & & \\
\hline Nilai CGSES & & & 0,090 \\
\hline Median & 4,00 & 4,00 & \\
\hline Range (min-max) & $2,00-4,00$ & $1,00-4,00$ & \\
\hline
\end{tabular}

Tabel 3. Perbandingan antara Skala Disabilitas SGB Pada Saat Masuk dan pada Saat Pulang Perawatan Pasien SGB dengan dan Tanpa Imunoterapi

\begin{tabular}{|c|c|c|c|c|c|c|}
\hline \multirow[t]{2}{*}{ Variabel } & \multicolumn{2}{|c|}{ Dengan Imunoterapi } & \multirow[t]{2}{*}{ Nilai P } & \multicolumn{2}{|c|}{ Tanpa Imunoterapi } & \multirow[t]{2}{*}{ Nilai P } \\
\hline & $\begin{array}{l}\text { Saat Masuk } \\
\mathrm{n}=35\end{array}$ & $\begin{array}{l}\text { Saat Pulang } \\
\mathrm{n}=35\end{array}$ & & $\begin{array}{l}\text { Saat Masuk } \\
\mathrm{n}=57\end{array}$ & $\begin{array}{l}\text { Saat Pulang } \\
\mathrm{n}=57\end{array}$ & \\
\hline Skala Disabilitas SGB & & & $0,007 *$ & & & $0,025^{*}$ \\
\hline Sehat $(0)$ & $0(0,0 \%)$ & $0(0,0 \%)$ & & $1(1,8 \%)$ & $1(1,8 \%)$ & \\
\hline $\begin{array}{l}\text { Ringan, dapat berlari } \\
\text { (1) }\end{array}$ & $0(0,0 \%)$ & $4(11,4 \%)$ & & $2(3,5 \%)$ & $6(10,5 \%)$ & \\
\hline $\begin{array}{l}\text { Jalan tanpa bantuan } \\
\text { (2) }\end{array}$ & $3(8,6 \%)$ & $9(25,7 \%)$ & & $18(31,6 \%)$ & $22(38,6 \%)$ & \\
\hline $\begin{array}{l}\text { Jalan dengan bantuan } \\
\text { (3) }\end{array}$ & $2(5,7 \%)$ & $2(5,7 \%)$ & & $15(26,3 \%$ & $6(10,5 \%)$ & \\
\hline $\begin{array}{l}\text { Tirah baring, tidak } \\
\text { dapat jalan (4) }\end{array}$ & $16(45,7 \%)$ & $14(40,0 \%)$ & & $21(36,8 \%)$ & $21(36,8 \%)$ & \\
\hline Memerlukan VM (5) & $14(40,0 \%)$ & $1(2,9 \%)$ & & $0(0,0 \%)$ & $0(0,0 \%)$ & \\
\hline Meninggal(6) & $0(0,0 \%)$ & $5(14,3 \%)$ & & $0(0,0 \%)$ & $1(1,8 \%)$ & \\
\hline
\end{tabular}

Keterangan: Nilai kemaknaan berdasarkan nilai $\mathrm{p}<0,05$. Tanda* menunjukkan nilai $\mathrm{p}<0,05$ artinya signifkan atau bermakna secara statistik.

nilai CGSES pada kedua kelompok imunoterapi dan tanpa imunoterapi (median 4, $\mathrm{p}=0,09$ ). Tabel 3 menjelaskan perbandingan antara SDSGB pada saat masuk dan pada saat pulang perawatan pasien SGB dengan dan tanpa imunoterapi. Pada saat masuk perawatan, kelompok pasien dengan imunoterapi mempunyai SDSGB yang lebih berat dibandingkan dengan yang tidak menjalani 
Tabel 4. Perbandingan antara Kesesuaian Keputusan Klinis dengan Penilaian CGSES dalam Pemberian Imunoterapi pada Pasien SGB

\begin{tabular}{lllll}
\hline Variabel & CGSES & & $\begin{array}{l}\text { Nilai Kappa } \\
(\text { CI 95\%) }\end{array}$ & Nilai P \\
& $\begin{array}{l}\geq 3 \\
\mathrm{n}=81\end{array}$ & $\mathrm{n}=11$ & & \\
\hline Kelompok & & & 0,117 & $0,035^{*}$ \\
$\begin{array}{l}\text { Dengan } \\
\text { Imunoterapi }\end{array}$ & $34(42,0 \%)$ & $1(9,1 \%)$ & $(0,213-0,021)$ & \\
Tanpa Imunoterapi & $47(58,0 \%)$ & $10(90,9 \%)$ & & \\
\hline
\end{tabular}

Keterangan: Tanda* menunjukkan nilai $\mathrm{p}<0,05$ artinya signifkan atau bermakna secara statistik

imunoterapi. Sebanyak $45,7 \%$ tirah baring dan tidak dapat berjalan, dan $40 \%$ memerlukan ventilator mekanik. Kelompok yang tidak menjalani imunoterapi mempunyai SDSGB yang ringan; $31,6 \%$ masih dapat berjalan tanpa bantuan, $26,3 \%$ dapat berjalan dengan bantuan, dan 36,8\% memerlukan tirah baring karena tidak dapat berjalan. Tidak ada subyek pada kelompok tanpa imunoterapi yang memerlukan bantuan ventilator mekanik saat masuk perawatan. Pada saat pulang, $14,3 \%$ pasien pada kelompok dengan imunoterapi pulang dalam keadaan meninggal. Terdapat pergeseran nilai SDSGB pada pasien yang bertahan hidup, dengan perbedaan persentase yang signifikan secara statistik antara SDSGB pada saat masuk dan pada saat pulang $(p=0,007)$. Satu orang pasien tanpa imunoterapi meninggal dalam perawatan. dan juga didapatkan pergeseran ke arah lebih baik pada SDSGB saat pulang dibandingkan dengan saat masuk pada kelompok tanpa imunoterapi $(\mathrm{p}=0,025)$.

Tabel 4 menjelaskan perbandingan antara kesesuaian keputusan klinis dengan penilaian CGSES dalam pemberianimunoterapi pada pasien SGB. Didapatkan perbedaan persentase yang signifikan secara statistik antara variabel kategori nilai CGSES pada kelompok pasien dengan imunoterapi dan kelompok tanpa imunoterapi $(\mathrm{p}=0,035)$, namun tidak didapatkan kesesuaian keputusan klinis secara subyektif dengan nilai CGSES (nilai $\kappa=0,117$ ). Terdapat beberapa alasan mengapa pasien dengan nilai CGSES $\geq 3$ tidak dilakukan imunoterapi $(\mathrm{n}=47 ; 58 \%)$, antara lain pertimbangan dari dokter penanggung jawab untuk melakukan observasi terlebih dahulu $(n=24 ; 51,1 \%)$, fasilitas yang tersedia yaitu ruang intensif penuh $(\mathrm{n}=20 ; 42,55 \%)$, keterbatasan biaya pasien $(n=3 ; 4,25 \%)$ dan kondisi pasien yang tidak stabil berupa tanda-tanda vital yang jelek sehingga tidak memungkinkan untuk dilakukan imunoterapi $(\mathrm{n}=1 ; 2,12 \%)$.

Nilai CGSES dapat digunakan dalam penentuan pemberian imunoterapi yaitu bila nilai CGSES 3 atau 4. Pada penelitian ini pada kelompok pasien dengan imunoterapi, untuk nilai CGSES kategori $\geq 3$ sebanyak 34 atau sebesar $42 \%$ dan kategori $<3$ sebanyak 1 atau sebesar 9,1\%. Terdapat 1 subjek dengan nilai CGSES $<3$ tetapi subjek tetap diberikan imunoterapi karena pada saat datang subjek sudah dalam skala disablitas SGB yang berat yaitu 5 yang membutuhkan ventilator (SGB dengan kelemahan otot pernafasan), sehingga langsung dilakukan tindakan imunoterapi di ICU. Nilai CGSES kecil karena durasi waktu antara onset sampai datang ke RS cukup lama yaitu 14 hari. Hal ini sesuai dengan Nilai CGSES yang ditentukan oleh 4 kategori yaitu keluhan utama berupa keluhan kelemahan, sensorik, keterlibatan saraf kranial dan onset dari sejak keluhan sampai datang ke RS. Dengan memakai nilai CGSES, hanya berlandaskan pada keluhan utama saja bisa menentukan keparahan dan perlunya imunoterapi. ${ }^{5}$ Akan tetapi keputusan klinis tetap didasarkan juga pada kondisi pada saat pasien datang ke RS, sehingga 1 subjek tersebut tetap dilakukan imunoterapi juga. Pada penelitian-penelitian sebelumnya imunoterapi direkomendasikan pada $\mathrm{SDSGB} \geq 3$, di mana skala tersebut setara dengan nilai CGSES 3 atau 4 pada fase nadir. ${ }^{1,5,7}$ Pada kelompok pasien tanpa imunoterapi sebagian besar yaitu sebanyak 47 subjek ( $82 \%$ ) dengan nilai CGSES $\geq 3$, di mana 
seharusnya pasien mendapakan imunoterapi, hal-hal yang menyebabkan tidak dilakukannya imunoterapi pada pasien ini antara lain adalah pertimbangan dari dokter untuk mengobservasi keadaan pasien karena melihat tidak adanya perburukan klinis dan kondisi pasien yang stabil sebanyak 24 subjek $(51,1 \%)$, ketidaktersediaan ruang intensif sebanyak 20 subjek (42,55\%), keterbasan biaya masing-masing sebanyak 2 subjek $(4,25 \%)$ dan alasan yang terakhir adalah pertimbangan kondisi pasien yang sudah jelek sehingga tidak memungkinkan dilakukan imunoterapi sebanyak 1 subjek $(2,12 \%)$.

Pertimbangan dari dokter untuk menunda dahulu tindakan imunoterapi, dapat didasarkan pada kondisi tanda-tanda vital pasien yang stabil dan melihat juga kekuatan motorik pasien pada saat datang yang tidak berat. Ketidaktersediaan fasilitas yaitu ruangan intensif untuk melakukan imunoterapi dikarenakan RSUP dr. Hasan Sadikin merupakan RS rujukan provinsi sehingga ruang intensif sering dalam kondisi penuh karena diisi pasien-pasien dari bagian-bagian lain selain saraf dengan masa perawatan yang cukup panjang, sehingga perlu waktu untuk menunggu ketersediaan ruang rawat. Dalam masa observasi di ruang biasa banyak pasien sudah melewati fase nadir dengan kondisi tanda-tanda vital yang stabil, sehingga pasien dapat dipulangkan tanpa penatalaksanaan imunoterapi. Keterbatasan biaya merupakan alasan berikutnya yaitu pasien dengan biaya umum yang tidak mempunyai asuransi kesehatan. Terdapat 1 subjek yang pada masa perawatan mengalami perburukan kondisi karena sepsis sehingga masuk ke ruang intensif untuk observasi, akan tetapi subjek tidak dapat dilakukan imunoterapi karena kondisi tanda-tanda vital yang tidak stabil dan akhirnya meninggal, sehingga belum sempat dilakukan imunoterapi. Hasil uji statistik pada kelompok penelitian diatas diperoleh informasi nilai $p$ pada variabel Kategori Nilai CGSES lebih kecil dari 0,05 (nilai $p=0,035$ ) yang berarti signifikan atau bermakna secara statistik dengan demikian dapat dijelaskan bahwa terdapat perbedaan persentase yang signifikan secara statistik antara variabel kategori nilai CGSES pada kelompok pasien dengan imunoterapi dan kelompok tanpa imunoterapi. Secara stastistik juga didapatkan kekurangsesuaian antara nilai CGSES dengan keputusan klinis (kappa 0,117) dengan Confidence Interval $(0,213-0,021)$.

\section{Pembahasan}

Pada penelitian ini tidak terdapat perbedaan rerata umur subjek SGB dengan dan tanpa imunoterapi $(40,3$ tahun vs. 42,5 tahun, $p=0,460)$. Nilai rerata usia ini tidak jauh berbeda dengan hasil studi di India di mana rerata umur pasien SGB yang mendapatkan imunoterapi adalah 40,69 tahun. $^{8}$ Pada penelitian ini rasio pria dibanding wanita pada kejadian SGB dengan imunoterapi tidak jauh berbeda, yaitu 1,3:1, dan pada kelompok SGB tanpa imunoterapi, rasio pria dan wanitanya 1,4: 1. Hal ini sesuai dengan penelitian di Jepang yang menyatakan angka insidensi terjadinya SGB lebih tinggi pada pria dibanding wanita dengan rasio jenis kelamin pria dibanding wanita berkisar 1,25: 1; dan hal ini ini konsisten dengan hampir semua penelitian tentang SGB.9 Sebagai catatan, insidensi terjadinya SGB bisa meningkat pada wanita bila memiliki keadaan-keadaan tertentu seperti adanya penyakit autoimun seperti multiple sclerosis, penyakit reumatik, sclerosis lupus eritematous (SLE), adanya kondisi preeclampsia, dan riwayat transfusi. ${ }^{10}$

Pada penelitian ini kejadian anteseden yang terbanyak adalah diare dan infeksi saluran nafas, baik pada kelompok dengan ataupun tanpa imunoterapi. Penelitian di Amerika juga mendapatkan bahwa dua pertiga dari pasien SGB mempunyai kejadian anteseden sebesar 40-70\%; dengan $22-53 \%$ berupa infeksi saluran pernapasan atas dan 6-26\% berupa infeksi saluran cerna. ${ }^{11} \mathrm{Hal}$ ini juga sesuai dengan penelitian Islam B di Bangladesh yang menyatakan pasien yang dilakukan imunoterapi berupa PE menpunyai infeksi anteseden berupa diare dan infeksi saluran nafas. ${ }^{12}$ Pada penelitian ini secara klinis kelompok SGB dengan imunoterapi ditandai dengan adanya defisit sensorik $(65,7 \%)$, adanya defisit motorik (100\%) dan paresis saraf kranial $(62,9 \%)$. Hasil ini sesuai dengan penelitian di Bangladesh yang mendapatkan bahwa pasien SGB yang dilakukan imunoterapi dapat memiliki 
ketiga gejala klinis tersebut. ${ }^{12}$ Pada penelitian ini kelainan saraf kranial lebih banyak dijumpai pada kelompok yang menjalani imunoterapi. Hal ini sesuai dengan apa yang didapatkan di Cina dan India. Keluhan/tanda kelainan saraf kranial merupakan prediktor keparahan SGB, sehingga diperlukan imunoterapi. ${ }^{5,13}$ Varian SGB berdasarkan pemeriksaan KHS yang paling sering ditemukan pada penelitian ini baik pada kelompok imunoterapi maupun tanpa imunoterapi adalah AMSAN (51,4\% pada kelompok dengan imunoterapi dan $57,9 \%$ pada kelompok tanpa imunoterapi).

Hasil penelitian ini berbeda dengan beberapa studi epidemiologi di Asia, seperti Tiongkok dan Jepang, di mana varian yang sering ditemukan adalah varian AMAN, sedangkan insidensi varian AMSAN di Asia dikatakan ditemukan sebanyak 4\% di Jepang, $6 \%$ di India, dan sebanyak 11\% di Bangladesh., ${ }^{9} 14$ Subjek dengan varian AMAN dan AMSAN dapat mempunyai penanda serologis yang sama. Pada varian AMSAN memiliki penanda imunologi yang sama dengan varian AMAN yaitu IgG anti-GM1 dan anti-GD1a, antibodi yang membedakan varian AMAN dari varian AIDP. Profil imunologi secara umum ini mendukung asumsi bahwa varian AMAN dan AMSAN mungkin timbul sebagai akibat dari respons imun yang sama terhadap akson, bukan dua perjalanan penyakit yang berbeda. Pemeriksaan KHS sensorik serial mengidentifikasi bahwa serabut sensorik sering secara subklinis terlibat dalam varian AMAN dan gambaran blok konduksi terjadi pada serabut sensorik dan motorik pada varian AMAN dan AMSAN. Dengan demikian, varian AMSAN dapat dianggap sebagai varian AMAN yang mempunyai kelainan lebih banyak pada akson di serabut sensorik. ${ }^{14}$

Pada penelitian ini, rata-rata median awitan sampai RS dari kelompok imunoterapi dan tidak mendapatkan imunoterapi hanya berbeda 1 hari yaitu 4 hari pada kelompok imunoterapi dan 5 hari pada kelompok tanpa imunoterapi. Pada kelompok dengan imunoterapi rentang waktu dari awitan sampai ke RS yaitu dari 1 sampai dengan 14 hari. Pada penelitian yang dilakukan di
Bangladesh didapatkan nilai median untuk durasi awitan sampai RS yaitu selama 7 hari dengan rentang waktu selama 1-12 hari, sedangkan suatu penelitian lain di Cina didapatkan nilai median selama 5 hari dengan rentang waktu 3 sampai dengan 8 hari. ${ }^{5,12}$ Perbedaan nilai durasi awitan - RS ini dapat berkaitan dengan kesadaran pasien untuk cepat datang ke rumah sakit dan beratnya gejala. Pada penelitian ini, tidak didapatkan perbedaan durasi awitan - RS yang signifikan antara kelompok SGB dengan imunoterapi atau tanpa imunoterapi.

Pada penelitian ini rata-rata durasi awitan sampai pelaksanaan imunoterapi adalah $8,2 \pm 4,3$ hari dengan rentang waktu dari 2 sampai dengan 21 hari. Hal ini hampir sama dengan penelitian yang dilakukan di Jepang di mana rentang waktu berkisar antara 4 sampai dengan 20 hari (rata-rata 10,4 hari). ${ }^{15}$ Pelaksanaan imunoterapi pada penelitian ini tidak terlambat, dan hal ini sesuai dengan peneltian-penelitian sebelumnya yang menyatakan bahwa imunoterapi dapat memberikan efek terapeutik yang lebih baik bila dilakukan dalam 2 minggu pertama onset. ${ }^{16}$ Pada penelitian ini rata-rata lama rawat kelompok imunoterapi lebih lama dari yang tidak menjalani imunoterapi $(29,5 \pm 34,4$ hari vs. $11,4 \pm 4,1$ hari). Durasi perawatan pada pasien dengan imunoterapi lebih panjang tidak selamanya dikarenakan oleh tindakan imunoterapi, melainkan adanya faktor perancu antara lain lebih banyaknya pasien dengan SDSGB yang berat pada waktu datang ke RS dan adanya komplikasi yang terjadi pada saat perawatan. Komplikasi saat perawatan seperti komplikasi paru yaitu pneumonia sehingga pasien membutuhkan alat bantu nafas atau VM, dan pemakaian VM ini yang akan meningkatkan lama perawatan di RS. Hal ini sesuai dengan penelitian yang dilakukan di Cina di mana pada pasien yang dilakukan imunoterapi yang mengalami gagal nafas membutuhkan VM sehingga menyebabkan durasi perawatan yang makin lama. ${ }^{17}$ Pada penelitian ini didapatkan pasien dengan imunoterapi yang dirawat lama dikarenakan adanya gagal nafas yang membutuhkan ventilator dan membutuhkan pemulihan sehingga memperlama durasi perawatan. 
Pada penelitian ini, didapatkan angka kematian yang lebih tinggi pada kelompok dengan imunoterapi yaitu 5 orang $(11,4 \%)$, dibandingkan dengan 1 orang $(1,8 \%)$ pada kelompok tanpa imunoterapi. Penyebab kematian pada kelompok dengan imunoterapi adalah adanya komplikasi gagal nafas selama perawatan. Pada kelompok dengan imunoterapi didapatkan cukup banyak pasien dengan SDSGB berat, dimana 3 dari 5 kematian pada kelompok ini terjadi pada subjek dengan SDSGB 5.

Sebagai perbandingan, penyebab kematian pada 1 subjek di kelompok tanpa imunoterapi adalah sepsis karena pneumonia, dan sebenarnya dalam pertimbangan subyektif pasien memerlukan tindakan imunoterapi namun tidak dapat dilakukan karena terkendala oleh keadaan klinis yang buruk. Temuan pada penelitian ini sesuai dengan suatu penelitian yang dilakukan di Amerika yang menyatakan tingkat kematian terjadi sebesar $2,58 \%$ di mana $11 \%$ nya memiliki komplikasi paru dan 9,1\% dengan intubasi endotrakeal yang merupakan prediktor kematian (OR 5,09, 95\% CI 3,21- 8,05). ${ }^{18}$ Prediktor mortalitas yang terkuat pada pasien SGB adalah adanya peningkatan usia (OR 1,08 per tahun) dan adanya penyakit komorbiditas atau komplikasi yang menyertainya (33,3\% jika ada vs. $1,6 \%$ jika tidak ada; OR, 31,5, 95\% CI 3,1-317,8, p=0,002).

Komplikasi paru dan gagal napas yang menyebabkan pasien harus dirawat di ICU menggunakan VM merupakan salah satu komorbiditas yang sering pada pasien SGB..$^{18,19}$ Pada penelitian ini, nilai CGSES pada kelompok imunoterapi berkisar antara 2 sampai dengan 4 . Nilai CGSES 2 hanya didapatkan pada 1 subjek penelitian $(2,85 \%)$, sedangkan sisanya $(n=34$; 97,14\%) mempunyai nilai CGSES 3 atau 4, yang merupakan indikasi untuk dilakukan imunoterapi. Pada kelompok tanpa imunoterapi nilai CGSES berkisar antar 1 sampai dengan 4, dan nilai CGSES $<3$ didapatkan pada 10 subjek $(17,54 \%)$, dan nilai CGSES $\geq 3$ sebanyak 47 subjek $(82,45 \%)$. Tidak terdapat perbedaan rerata nilai CGSES yang signifikan secara statistik $(\mathrm{p}=0,090)$ pada kedua kelompok.
Pada penelitian ini, lebih dari 50\% subjek pada kelompok dengan imunoterapi mempunyai nilai SDSGB saat masuk skala 4 dan 5, yaitu tergolong SDSGB yang berat $(\geq 3)$ Subjek dengan skala 5 (memerlukan ventilator mekanik) langsung menjalani pemberian imunoterapi dan dirawat di ruang intensif untuk monitor ketat. Pada saat pulang didapatkan perbaikan SDSGB pada kelompok ini, yaitu subjek dengan SDSGB 5 mengalami penurunan persentase dari $40 \%$ menjadi 2,9\%, dan subjek dengan SDSGB 1 mengalami peningkatan dari $0 \%$ menjadi $11,4 \%$; meskipun didapatkan $5(14,3 \%)$ subjek yang meninggal (skala SDSGB 6). Penyebab kematian pada ke-5 subjek tersebut adalah gagal nafas akibat infeksi paru, dan tiga dari lima subjek tersebut datang dengan SDSGB 5. Pneumonia sebagai penyebab kematian pasien SGB juga dijumpai pada studi di Italia.20 Pada beberapa studi lain didapatkan penyebab kematian pada pasien SGB yang paling sering adalah gagal nafas, pneumonia, henti jantung dan disfungsi otonom. ${ }^{2}$ Pemberian imunoterapi dapat mempercepat pemulihan dari pasien SGB ditandai dengan peningkatan satu poin atau lebih pada SDSGB setelah 4 minggu, dibandingkan tanpa pemberian imunoterapi (Relative Risk 1,64 CI 95\% 1,37$1,96, \mathrm{p}=0,00001){ }^{6}$

Nilai SDSGB saat masuk pada kelompok tanpa imunoterapi terbanyak adalah skala $4(\mathrm{n}=21$; $36,8 \%)$, diikuti skala $2(\mathrm{n}=18 ; 31,6 \%)$ dan skala $3(\mathrm{n}=15 ; 26,3 \%)$. Pada saat pulang didapatkan perbaikan SDSGB pada kelompok ini yaitu skala 3 dari $26,3 \%$ menjadi $10,5 \%$, skala 2 dari $31,6 \%$ menjadi $38,6 \%$ dan skala 1 dari 3,5\% menjadi $10,5 \%$. Didapatkan 1 subjek yang meninggal saat pulang (SDSGB 6) dengan penyebab kematian gagal nafas akibat pneumonia. Sebagaimana kelompok dengan imunoterapi, pada kelompok tanpa imunoterapi juga didapatkan perubahan skor SDSGB yang signifikan secara statistik. Penilaian keadaan klinis untuk memutuskan pemberian imunoterapi seringkali didasarkan pada pertimbangan subyektif dokter yang merawat. Adanya penilaian obyektif yang praktis akan sangat membantu keputusan klinis ini. CGSES merupakan skoring yang sederhana yang diharapkan dapat membantu menyelesaikan 
masalah ini, dimana pada penelitian-penelitian sebelumnya imunoterapi direkomendasikan pada nilai SDSGB 3 atau lebih..$^{1,5,7}$ Penelitian ini melakukan analisis penilaian kesesuaian keputusan klinis pemberian imunoterapi dengan nilai CGSES yang dihitung kemudian. Didapatkan ketidaksesuaian keputusan klinis dengan nilai CGSES (kappa 0,117).

Pada kelompok pasien tanpa imunoterapi sebagian besar $(\mathrm{n}=47,82 \%)$ dengan nilai CGSES $\geq 3$, di mana seharusnya pasien mendapakan imunoterapi. Hal-hal yang menyebabkan tidak dilakukannya imunoterapi pada pasien ini antara lain adalah pertimbangan dari dokter yang merawat untuk mengobservasi keadaan pasien karena tidak melihat adanya perburukan klinis dan kondisi pasien yang stabil $(\mathrm{n}=24 ; 51,1 \%)$, ketidaktersediaan ruang intensif $(\mathrm{n}=20 ; 42,55 \%)$, keterbatasan biaya $(\mathrm{n}=2 ; 4,25 \%)$ dan pertimbangan keadaan umum pasien yang jelek sehingga tidak memungkinkan dilakukan imunoterapi $(n=1$; $2,12 \%$ ). Pertimbangan dari dokter yang merawat untuk menunda tindakan imunoterapi, dapat didasarkan pada kondisi tanda-tanda vital pasien yang stabil dan melihat juga kekuatan motorik. Ketidaktersediaan fasilitas ruangan intensif sering didapatkan karena keterbatasan ruang intensif di rumah sakit, dan seringkali dalam masa observasi di ruang biasa pasien sudah melewati fase nadir dengan kondisi tanda-tanda vital yang stabil, sehingga pasien dapat dipulangkan tanpa imunoterapi. Keterbatasan biaya biasanya terkait pada ketiadaan asuransi pada saat perawatan.

Penelitian ini dilakukan secara retrospektif dengan menggunakan data dari rekam medis atau data sekunder dimana kelemahan dari penelitian yang bersumber pada data sekunder adalah ketidaklengkapan data. Selanjutnya varian SGB pada kelompok SGB dengan dan tanpa imunoterapi tidak seluruhnya diketahui karena pasien meninggal sebelum dilakukan neurofisiologi. Selain itu durasi lama perawatan pasien SGB yang tidak sama mempengaruhi dalam pengukuran SDSGB, di mana pasien yang pulang lebih awal belum bisa dilihat perbaikan SDSGB nya secara optimal.

\section{Simpulan}

Terdapat perbedaan hasil penilaian CGSES pada pasien SGB dengan dan tanpa imunoterapi dan terdapat perbedaan nilai SDSGB pada saat masuk dan pulang perawatan pasien SGB dengan dan tanpa imunoterapi. Serta terdapat ketidaksesuaian penilaian subyektif keputusan pemberian imunoterapi dengan skoring CGSES.

\section{Daftar Pustaka}

1. Ahmad S, Aida F, Hasnawi H, Suryani G. Pedoman Tatalaksana GBS, CIDP, MG dan Imunoterapi.; 2018.

2. Van den Berg B, Walgaard C, Drenthen J, Fokke C, Jacobs BC, van Doorn PA. Guillain-Barré syndrome: pathogenesis, diagnosis, treatment and prognosis. Nat Rev Neurol. 2014;10(8):469-82.

3. Shahrizaila N, Yuki N. The role of immunotherapy in Guillain-Barré syndrome: understanding the mechanism of action. Expert Opin Pharmacother.

4. Reeves HM, Winters JL. The mechanisms of action of plasma exchange. Br J Haematol. 2014;164(3):342-51.

5. Wang Y, Shang $P$, Xin M, Bai J, Zhou C, Zhang H-L. The usefulness of chief complaints to predict severity, ventilator dependence, treatment option, and shortterm outcome of patients with GuillainBarré syndrome: a retrospective study. BMC Neurol. 2017;17(1):200.

6. Chevret S, Hughes RA, Annane D. Plasma exchange for Guillain-Barré syndrome. Cochrane Neuromuscular Group, ed. Cochrane Database Syst Rev. Published online February 27, 2017.

7. van Doorn PA, Ruts L, Jacobs BC. Clinical features, pathogenesis, and treatment of Guillain-Barré syndrome. Lancet Neurol. 2008;7(10):939-50. 
8. Shrivastava M, Nehal S, Seema N. GuillainBarre syndrome: Demographics, clinical profile \& seasonal. INDIAN J MED RES. Published online 2017:6.

9. Kuwabara S. Guillain-Barré syndrome epidemiology, pathophysiology and management. Published online 2004:14.

10. Auger N, Quach C, Healy-Profitós J, Dinh T, Chassé M. Early predictors of Guillain-Barré syndrome in the life course of women. Int $\mathrm{J}$ Epidemiol. 2018;47(1):280-88.

11. McGrogan A, Madle GC, Seaman HE, de Vries CS. The Epidemiology of Guillain-Barré Syndrome Worldwide. Neuroepidemiology. 2009;32(2):150-163.

12. Islam $B$, Islam $Z$, Rahman $\mathrm{S}$, Endtz $\mathrm{H}$, Vos M, Van der M, Van Doorn P. Small volume plasma exchange for Guillain-Barré syndrome in resource-limited settings: a phase II safety and feasibility study. BMJ Open. 2018;8(8):e022862.

13. Bhargava A, Banakar BF, Pujar GS, Khichar S. A study of Guillain-Barré syndrome with reference to cranial neuropathy and its prognostic implication. J Neurosci Rural Pract. 2014;05(S 01):S043-S047.

14. Bae JS, Yuki N, Kuwabara S, Kim JK, Vucic S, Lin CS, Kierman MC. GuillainBarre syndrome in Asia. J Neurol Neurosurg
Psychiatry. 2014;85(8):907-13.

15. Study Group for Pediatric Guillain-Barre Syndrome. High-dose immunoglobulin therapy for Guillain-Barre syndrome in Japanese children. Pediatr Int. 2003;45(5):543-49.

16. Liu S, Dong C, Ubogu EE. Immunotherapy of Guillain-Barré syndrome. Hum Vaccines Immunother. Published online June 28, 2018:1-12.

17. Tsai C-P, Wang K-C, Liu C-Y, Sheng W-Y, Lee T-C. Pharmacoeconomics of therapy for Guillain-Barré syndrome: plasma exchange and intravenous immunoglobulin. J Clin Neurosci. 2007;14(7):625-29.

18. Alshekhlee A, Hussain Z, Sultan B, Katirji B. Guillain-Barre syndrome: Incidence and mortality rates in US hospitals. Neurology. 2008;70(18):1608-13.

19. Dhar R, Stitt L, Hahn AF. The morbidity and outcome of patients with Guillain-Barré syndrome admitted to the intensive care unit. J Neurol Sci. 2008;264(1-2):121-28.

20. Chio A, Cocito D, Leone M, Giordana MT, Mora G, Mutani R. Guillain-Barre syndrome: A prospective, population-based incidence and outcome survey. Neurology. 2003;60(7):1146-50. 